Branislav Oblučar

University of Zagreb

boblucar@ffzg.hr

ORCID: 0000-0002-7222-165X
Data przesłania tekstu do redakcji: 11.11.2019

Data przyjęcia tekstu do druku: 23.12.2019

\title{
Avangarda poslije avangarde u hrvatskoj poeziji
}

Aвstract: Oblučar Branislav, Avangarda poslije avangarde u hrvatskoj poeziji (Avant-garde After the Avant-garde in Croatian Poetry). "Poznańskie Studia Slawistyczne" 18. Poznań 2020. Publishing House of the Poznań Society for the Advancement of the Arts and Sciences, Adam Mickiewicz University, pp. 159-173. ISSN 2084-3011.

The article discusses the problem of the avant-garde in Croatian poetry during the second half of $20^{\text {th }}$ century. It supports the thesis about the continuity of the avant-garde before and after World War II, and perceives the artistic and literary experiments of the neo and post-avant-garde as a part of a long avant-garde tradition. The analysis brings forward the different perceptions of avant-garde in the works of Radovan Ivšić and Josip Sever, and post-avant-garde poets of 1970s and 80s.

KeYwords: avant-garde; neo-avant-garde; post-avant-garde; postmodernism; poetry; Croatian literature

Na početku studije Poetika osporavanja Aleksandar Flaker $(1982,11)$ konstatira da je u 1970-im godinama pojam avangarde stekao pravo građanstva i u hrvatskoj, odnosno jugoslavenskoj sredini, i to izvan usko znanstvenih krugova. Iz današnje perspektive to može djelovati iznenađujuće jer obično imamo dojam da je termin bio itekako prisutan u samom razdoblju koje se njime opisuje, odnosno da su ga akteri književnih i umjetničkih pravaca prve trećine 20. st. koristili u vlastitom samoodređenju. Međutim, to nije bio slučaj, što naglašava i sam Flaker (1976, 199-200) kada navodi različite otpore stručnjaka prema usvajanju ,avangarde“ kao pojma književnopovijesne klasifikacije upravo zbog činjenice pomanjkanja umjetničkih ili književnih pokreta koji bi se u spomenutom razdoblju nazivali tim imenom. Na isti problem izostanka samoimenovanja recentno su upozorili i suvremeni proučavatelji avangarde poput Huberta van den Berga: za razdoblja povijesne avangarde umjetnici su ponajprije afirmirali 
pojedine ,izme“ kojima su pripadali i s kojima su se identificirali, želeći konkurirati drugim pravcima i nametnuti svoju viziju. Tek su se povremeno utjecali pojmu avangarde kada je trebalo označiti unutarnju koheziju, odnosno povezanost raznorodnih pravaca - postojala je naime svijest o avangardnosti, o ,umreženosti “1 pojedinih aktera, ali nije bilo potrebe da se označava nekim krovnim pojmom (van den Berg, 2013, 11-12). Ovakve teorijske opaske podsjećaju da je pojam ,avangarde“ ili „povijesne avangarde" književnopovijesna konstrukcija te stoga nudi različite mogućnosti argumentacije u smislu opsega njezine kronološke primjene, o čemu najbolje svjedoče prijepori o svemu onome što u umjetnosti i književnosti dolazi nakon povijesne avangarde, a na njezinoj pozadini - je li i to avangarda ili samo njezina blijeda repriza?

Situacija s prisutnošću samoga pojma mijenja se dakle nakon Drugog svjetskog rata, kada povijesna avangarda u Europi i Americi stječe široku recepciju, kao i nastavljače među umjetničkim grupama i pravcima (npr. Fluxus, Kobra ili Situacionistička internacionala) koji se sada sami prepoznaju kao avangarda, odnosno u novome kontekstu inzistiraju na kontinuitetu s postupcima i gestama povijesne avangarde, npr. dadaizma ili konstruktivizma. Tu „obnovu“ avangarde proučavatelji nazivaju neoavangardom i u drugoj polovici 20. st. često je proglašavaju neautentičnom, epigonskom ili „podgrijanom“ (Flaker, 1982, 31), želeći je jasnije odijeliti od „originalne“, prave, odnosno povijesne avangarde. Takva su vrednovanja bitno određena argumentacijom Petera Bürgera iz utjecajne Teorije avangarde (1974), gdje ustvrđuje da „,neoavangarda institucionalizira avangardu kao umjetnost i time negira izvorne avangardne intencije“ (Bürger, 2007, 97), a one se stječu u (neuspjelom) pokušaju pravaca da dokinu građansku instituciju umjetnosti i revolucioniraju društvo. Pri takvim prosudbama gubi se međutim iz vida činjenica da je riječ o transformaciji, a ne pukom ponavljanju, jer nasljedovanje avangardističkih gesta i tehnika poslije Drugog svjetskog rata nužno dobiva i novo značenje. Na to primjerice upućuje Anna Katharina Schaffner kada piše o konkretističkoj poeziji -

${ }^{1}$ Nastojeći izbjeći aporije jednoznačne definicije avangarde kao heterogenog fenomena, van den Berg $(2013,20)$ određuje je kao socijalnu konfiguraciju - promjenjivu i lutajuću, ali ipak jedinstvenu mrežu različitih umjetničkih grupa, časopisa i pojedinaca koji ,nastoje [...] da razviju novu umetnost, odnosno umetničku alternativu hegemonističkoj umetnosti svog doba". 
dok je suvremenici poput Hansa Magnusa Enzensbergera vide kao neodgovorni eksperiment opterećen akademskim žargonom, kritičarka ističe činjenicu da su dadaističke i futurističke tehnike vizualne i zvučne poezije u konkretizmu obogaćene novim spoznajama iz područja lingvistike, semiotike, filozofije jezika, teorije komunikacija i medija koje pjesnicima 1950-ih i 1960-ih omogućuju sofisticiranije i preciznije razumijevanje jezičnoga znaka (Schaffner, 2006, 99-100).

Van den Berg također vodi računa o kontekstualnim mijenama, ponajprije u okviru same institucije umjetnosti, ali upozorava i na kontinuitet između raznovremenih umjetničkih praksi - i neoavangarda, unatoč poricanju kritičara i teoretičara, prema njegovu mišljenju s povijesnom avangardom dijeli osnovne pretpostavke umjetničkog djelovanja: „kombinaciju radikalnih estetskih inovacija s pokušajem revolucioniranja ne samo umjetničkih praksi, nego društva u cjelini“" (van den Berg, 2005a, 64). S obzirom na to njemački kritičar neoavangardu vidi kao „kontinuirani nastavak predratne avangarde" (van den Berg, 2013, 20), a unutar toga kontinuiteta postoje dva razdoblja ,visoke konjunkture“ - prvo tijekom 1910-ih i 1920-ih, a drugo tijekom 1950-ih i 1960-ih, s vrhuncem u gibanjima oko 1968. i zalaznicom u 1970-ima (van den Berg, 2013, 21). Budući da pojam ,neoavangarda“ nosi pejorativne konotacije, iako se danas koristi u neutralnome smislu, van den Berg (2005a, 73) predlaže i njegovo odbacivanje u korist neodređenijeg naziva koji bi činjenici kontinuiteta pristupao deskriptivno - avangarda prije i poslije Drugoga svjetskog rata. Leksikon avangarde koji je autor sastavio zajedno s Walterom Fähndersom prikladna je ilustracija ovoga kontinuiteta: u njemu se uz pojmove povezane s književnim i umjetničkim pravcima povijesne avangarde pojavljuju ne samo oni vezani za neoavangardna stremljenja, već i za fenomene koji se smještaju bliže kraju 20. st. i katkad označavaju postavangardnima i postmodernističkima, a opisani su natuknicama ,punk“, „holopoezija“, „,hipertekst“, „,kompjuterska poezija“" i sl. ${ }^{2}$

${ }^{2}$ Kao primjer prikaza kontinuiteta različitih inačica avangarde na prostoru zemalja bivše Jugoslavije može se navesti zbornik Impossible Histories - Historical Avant-gardes, Neo-avant-gardes, and Post-avant-gardes in Yugoslavia, 1918-1991 (2003) koji su u suradnji s mrežom kritičara i znanstvenika iz Hrvatske, Slovenije i Srbije uredili Dubravka Đurić i Miško Šuvaković. Polazište zbornika je činjenica postojanja jedinstvenog kulturnog prostora bivših dviju Jugoslavija koji je implicirao prepletanje i neprestanu razmjenu ideja između 
Iz ovakve perspektive avangarda se više ne može sagledavati kao jedan i jedinstven neuspjeli pokušaj prevrata, već kao svojevrsna tradicija osporavanja, prekida ili negacije u odnosu na dominantne estetske i/ili društvene vrijednosti, pa kontinuitet diskontinuitetā postaje njezinim bitnim obilježjem. Avangardna ostvarenja time čine „otvoren niz“, kako piše Predrag Brebanović $(2016,35)$, zbog čega avangarda „nije samo istorijska kategorija, nego i nedovršeni projekt", jer uvijek otvara sadašnjost prema budućnosti, odnosno implicira paradoksalnu vremensku logiku, tijesan suodnos ,anticipacije i rekonstrukcije“: ,en avant se može ustanoviti tek a posteriori“ (Brebanović, 2016, 194). Neoavangarda, kao i bilo koji pokušaj revitalizacije intencija povijesne avangarde, u tome je smislu ,nedovršeni i nikada dovršivi proces“ njezinog razumijevanja (Brebanović, 2016, 192). Iz takva rakursa Brebanović sagledava Krležin lik i djelo u kontekstu jugoslavenske avangarde, ističući kontinuitet autorova djelovanja prije i poslije Drugoga svjetskog rata te njegovo avangardno utemeljenje - koje se jednako očituje u piščevoj avangardističkoj fazi oko Hrvatske književne laži, kao i u kreaciji projekta Enciklopedije Jugoslavije u smislu proizvoda ,jugoslovenske optimalne projekcije“ koja se iz prošlosti proteže u budućnost (Brebanović, 2016, 195). Brebanović time nudi primjer jednoga mogućeg razumijevanja (jugoslavenske) avangarde i Krleže kao njezine središnje figure; njegova polemička intervencija u polje krležoloških rasprava pokazuje da činjenica nacionalne kanonizacije ovoga pisca ne može okončati proces interpretacije njegova djela. Proučavanje avangarde, baš kao i ona sama, ne radi samo s tekstovima, već i s kontekstima (Brebanović, 2016, 40).

Pokušat ću u ostatku teksta ukazati na različite načine razumijevanja odnosno recepcije avangarde i bitne momente isticanja njezina kontinuiteta u kontekstu hrvatske književnosti nakon Drugog svjetskog rata, ponajprije u osloncu na pjesništvo, gdje su tragovi avangardnih postupaka bili najvidljiviji. Kao što je napomenuto na početku, avangarda se kao pojam tijekom 1970-ih utvrđuje unutar akademskog polja ponajprije zahvaljujući Flakeru i nizu proučavatelja koje oko sebe okuplja, a što kulminira u međunarodnom projektu Pojmovnika ruske avangarde u devet svezaka

različitih, a jezično i kulturno sličnih nacionalnih sredina (što 1990-ih kritičar Jerko Denegri [2003, xvi] naziva ,jugoslavenskim kulturnim prostorom“). 
(1984-1993) te rezultira proučavanjem i usustavljivanjem ideje hrvatske književne avangarde (primjer čega je i istoimena studija Gordane Slabinac iz 1988). U književnoj sferi za razgovor o avangardi važan je Zvonimir Mrkonjić i njegova studija Suvremeno hrvatsko pjesništvo (1971), u kojoj ovaj kritičar i pjesnik usustavljuje i valorizira poeziju triju desetljeća (od 1940-ih do kraja 1960-ih), postavljajući temelje brojnim kasnijim klasifikacijama. Pjesničku poratnu panoramu on promatra kao očitovanje triju različitih „,iskustava“, nazivajući ih iskustvom prostora, egzistencije i pisanja, pri čemu je kategorija ,pisanja“ (u smislu svijesti o pisanju kao tvorbenom i materijalnom činu) ona kojom Mrkonjić prvi put uspostavlja jasne poveznice između nekih važnih, a marginaliziranih, zatomljenih ili prešućenih pjesničkih glasova iz prethodnih desetljeća u kojima su evidentne geste i postupci koji nastaju na tragu avangarde ili - Flakerovim riječima - „u zoni djelovanja avangarde“ ${ }^{\text {(3) }}$. Upravo ta pjesnička imena poput svojevremeno prešućenog Radovana Ivšića, cenzuriranog Josipa Stošića, Bore Pavlovića, koji djeluje na krugovaškoj margini, i sl. postaju prethodnicima pjesništva ,iskustva jezika“ koje se na književnoj sceni pomalja 1960-ih i koje će se u potpunosti afirmirati upravo u 1970-ima, a bit će vitalno i u 1980-ima.

Indikativno je da Mrkonjić pritom ne koristi pojam avangarde, već ova raspršena iskustva u pjesničkom polju okuplja pod pojmom modernizma, ističući otpore spram modernističkih gesti kao važan dio njihova određenja: „modernizam nekog pjesnika određivalo je više odbijanje njegova čina od strane književne javnosti i njegovo vlastito odustajanje nego njegov apsolutni modernizam“ (Mrkonjić, 1971, 103). Poratni modernisti nisu dakle programski kolektivno nastupali, već su silom prilika bili „tumači neke osobne modernosti“ koja se u književnom polju sa stajališta dominantnih poetika (intimističke ili egzistencijalne) poimala poput „dječje bolesti“ koju treba preboljeti na putu pjesničkog sazrijevanja (Mrkonjić, 1971, 171). Težnja standardizaciji pjesničkog stila i ukusa (koju je

3 „Avangarda ima“, prema Flakerovu $(1982,343)$ mišljenju, ,vrlo izraženu paradigmatsku jezgru i vrlo široku zonu djelovanja“. Jezgra se odnosi na period 1910. - 1930., a zona je njezin vremenski obod u kojemu nastaju djela koja bez avangarde nije moguće shvatiti, ali njoj više ne pripadaju - Flaker kao primjer navodi Krležu. U interpretacijama pojedinačnih djela Flaker uvažava činjenicu kontinuiteta avangardnih postupaka, ali ostaje na pozicijama jasnih književnopovijesnih razgraničenja. 
primjerice 1950-ih zagovarao Antun Šoljan) rezultirala je potiskivanjem pluralnosti te ignoriranjem ,svakog udjela iracionalnog, ludičkog i drugih pokušaja da se prevrate granice poezijskog roda“, što je primjetno i u ,postupnom uklanjanju prisutnosti nadrealizma, dadaizma itd.“ (Mrkonjić, 1971, 171), dakle iskustava koja se oblikuju na pozadini modernističkog i avangardističkog nasljeđa.

Za uspostavljanje kontinuiteta između povijesne avangarde i poslijeratnih iskustava koja se oblikuju u zoni njezina djelovanja smatram naročito važnima dvojicu autora koje u svojoj studiji obrađuje Mrkonjić, a to su Radovan Ivšić i Josip Sever. Njihov je pristup avangardi drugačiji od pjesnika koji se na tragu njihovih postupaka javljaju kasnije. Pozicija Radovana Ivšića specifična je - on djeluje na zalaznici povijesne avangarde, svoje najvažnije tekstove piše pod utjecajem francuskog i srpskog nadrealizma s kojima se upoznaje krajem 1930-ih godina u Zagrebu. Po odlasku u Pariz 1954. susreće se s Benjaminom Peretom i Andréom Bretonom, koji prepoznaje dramu Kralj Gordogan kao nadrealistički tekst te Ivšić postaje članom pariškog nadrealističkog pokreta sve do njegova samoraspuštanja 1969. godine. Čitamo li njegove članke i intervjue okupljene u knjizi $U n e-$ povrat, opet (2002), jasno je da kod Ivšića iskustvo nadrealizma nije stvar prošlosti, već je itekako aktualno. Njegovo poimanje umjetnosti i poezije uvelike je u skladu s temeljnim postulatima i manifestima nadrealizma: inzistira na tome da nadrealizam nije literatura ili književni stil (,nema nadrealističkog stila“, Ivšić, 2002, 39), nego prakticiranje poezije koja je „prije svega način življenja“ (Ivšić, 2002, 39) i koja se napaja idejom slobode, traganjem za čudesnim, moralnim principima i sl.; izražava sklonost primitivnoj umjetnosti (,pučka je tradicija tradicija subverzije“, Ivšić, 2002, 51), ističe važnost pjesničke slike itd. U tom smislu, utopijska ili optimalna projekcija nadrealizma sastavni je dio njegovoga stava.

Upravo stoga što nadrealizam ne prepoznaje kao stil, za Ivšića se u stvaralačkom smislu ne može ustvrditi da je epigon ili oponašatelj načina pisanja koji je nakon Drugog svjetskog rata postao dijelom tradicionalne poezije u kojoj se izgubila „dijamantna tvrdoća sinteze kojom blistaju Bretonove i Charove slike“ (Mrkonjić, 1971, 115). Ivšićeva poema Narcis najbolji je primjer autorove stvaralačke invencije, u kojoj nadrealističke metaforičke vatromete odmjenjuju suptilni jezični pomaci, ponajprije na sintaktičkoj razini, koja je u nadrealista, kako ustvrđuje sam Ivšić, ostala 
nepravedno zanemarena, što se može razumjeti i kao rezultat hotimičnog uzmaka nakon dadaističkog razbijanja jezika (Ivšić, 2002, 45) 4 . Umjesto razbijanja Ivšić nudi subverziju iznutra: „na ivici jezika šuljaju se horde beskrajnih perspektiva... dovoljno je premjestiti putokaze sintakse" (Ivšić, 2002, 45). Naročito je zanimljiva njegova zamisao poeme kao korske recitacije u kojoj individualni glas unutar maloga kolektiva nalazi odjek u glasu drugoga; paradoksalno, njegovo stvaralaštvo ostaje bez odjeka Narcis je zaplijenjen 1942. od ustaških vlasti, a ni nakon 1945. autor ne uspijeva u potpunosti realizirati svoje stvaralačke zamisli - njegovoj je dramskoj družini vlast zabranila nastupanje, a nakon propasti lutkarskog teatra kojim se bavi odlazi u Pariz; njegovu je privremenom brisanju pridonijelo i isključivanje iz članstva Društva hrvatskih književnika. Zvonimir Mrkonjić je kritičar koji ga 1970-ih rehabilitira te tumači njegov pjesnički i teatarski rad.

Utoliko je indikativan Ivšićev stav spram pojma avangarde - $u$ intervjuu iz 1983. istaknuo je da mu je riječ u kontekstu poezije i teatra sumnjiva jer ima vojničke konotacije. U prepoznavanju avangarde kao „,vojničke metafore" rezonira Baudelaireova 19-ostoljetna osuda pisaca avangarde kao onih koji se pokoravaju vojničkoj disciplini na račun individualnosti, što Ivšić $(2002,86)$ potvrđuje preferirajući pojam „moderno u baudelaireovskom smislu te riječi“ za pisce poput Rimbauda i Lautréamonta. Avangarda je za Ivšića ždanovizam, autor je svrstava u striktno političku domenu i povezuje s totalitarizmima - on nipošto ne odriče političnost nadrealizmu, ali ga smješta bliže anarhizmu i trockističkoj ljevici. U Ivšićevim stavovima može se prepoznati nastavak prijepora nadrealizma i komunističke partije iz 1930-ih, pa i njegovo oštro razračunavanje s Markom Ristićem (Ivšić, 2002, 88-108) kao nadrealistom koji se priklonio partiji može se razumjeti na pozadini sukoba Breton - Aragon. Ova skepsa spram (političke) avangarde lako se može povezati s činjenicom da je u poraću cenzuriran, ali i s ogorčenjem zbog toga što je Ristić kao jedan od njegovih umjetničkih uzora postao zastupnikom (ambasadorom) režima koji ga je sputavao. No takvo svođenje avangarde na ždanovizam i socrealizam propušta vidjeti specifičnu poziciju umjetničke avangarde u jugoslavenskom

${ }^{4}$ Opsežnu analizu Narcisa izložio sam u članku „Narcis Radovana Ivšića - poema u obzoru avangarde" (Oblučar, 2015). 
socijalizmu koja se nakon napuštanja sovjetskog kulturnog modela tijekom 1950-ih ne može jednostavno svesti na naraciju o totalitarizmu i cenzuri.

Odnos Josipa Severa spram avangarde bitno je drugačiji od Ivšićeva, iako ne bez točaka podudarnosti. Dok Ivšić poima nadrealizam kao nešto još uvijek živo, čega je sam dio, Sever avangardu prepoznaje kao tradiciju, kao historijski fenomen: ujedno je reinterpretira na razini pjesničkih postupaka i historizira u smislu estetsko-revolucionarnog projekta. Severov pjesnički prvijenac Diktator (1969) smatra se jednom od prekretničkih knjiga hrvatske poezije, ona je postala ,simbolom urote protiv zatečenog stanja i ishodišnim mjestom razlistavanja nove poetike“" (Bagić, 1994, 65), a književna kritika sustavno je opisala pjesničke postupke kojima autor u toj i sljedećoj zbirci Anarhokor oblikuje vlastitu poetiku te istaknula ruski futurizam kao tradiciju na koju se on najočitije dovezuje. Severova pjesnička reinterpretacija avangarde počiva tako na „eufonijskim gestama“ (Bagić, 1994, 69-87) kojima se zvuku riječi daje primat u odnosu na smisao (poznata pjesnikova deviza da „zvuk diktira smisao“), na aktiviranju vizualne razine pjesničkog znaka i igranju prostorom teksta, na oblikovanju pjesme kao montaže fragmenata, na raspršenoj citatnosti i intertekstualnosti kao i na poigravanju motivima militarističkog podrijetla koji prizivaju avangardističku metaforiku.

Ipak, da bi se potpunije shvatila Severova historizacija avangarde, nije dovoljno zaustaviti se na imanentnoj razini pjesničkih tekstova iz autorovih dviju zbirki, na što je upozorio Lujo Parežanin (2015) u tekstu „Pjesništvo Josipa Severa i problemi proučavanja avangarde“. Svojom analizom Parežanin upućuje na važnost kontekstualnog pristupa Severu iz pomalo iskošene perspektive: prigodničarskih pjesama koje su povodom obljetnica Prvoga maja i Oktobarske revolucije objavljene na naslovnicama časopisa Oko 1975. i 1979. godine. Riječ je o četirima pjesmama, od kojih su tri uvrštene u zbirku Borealni konj (1989) $)^{5}$, i danas najreprezentativniji pregled autorova stvaralaštva; sve do Parežanina, koji ih čita unutar izvornoga novinskog konteksta u kojemu su objavljene - one nisu naišle na svoga tumača. Najvredniji Parežaninov uvid tiče se relativiziranja

${ }^{5}$ Riječ je o pjesmama: Plakat (u stilu ondašnjih plakata); Poslanica proleterskim piscima: Vladimir Majakovski /razgovara s Josipom Severom/ povodom 1. maja; Stilske vježbe V. Majakovskog i njegovog tima na temu 1-ga maja uz komentar J. Severa; LEF (ili nekoliko riječi u povodu 1. maja). 
općeprihvaćenog stava stručne kritike o Severovoj poziciji u odnosu na povijesnu avangardu, a koji je najpreciznije formulirala Dubravka Oraić Tolić u važnome eseju „Civilizacijski nomadizam Josipa Severa“: prema njezinu mišljenju, u Severovu nasljedovanju povijesne avangarde izostaje njezin sastavni dio - utopijski supstrat. Kod autora je na djelu dekonstrukcija utopijskih projekcija povijesne avangarde, pa je avangardistički tip montaže orijentirane prema budućnosti odmijenjen postmodernističkom montažom čiji je vremenski horizont određen sadašnjicom, bez ,vertikalnog" kretanja naprijed (Oraić Tolić, 1989, 17). Estetika prevrednovanja i „rušenja tradicionalne civilizacije“ zamijenjena je estetikom nivelacije i ,čuvanja svega postojećega“ (Oraić Tolić, 1989, 19): vjera u ideju ustupila je mjesto ravnodušnosti. Ostala je još samo jezična magija. Severove prigodničarske pjesme i kontekst njihove objave ovakve teze dovode u pitanje, upozoravajući na to da je autorov odnos spram povijesne avangarde ipak složeniji.

Stoga se pjesme iz Severovih zbirki u kojima je na djelu niveliranje raspršenih „civilizacijskih smislova“ nužno trebaju čitati u dosluhu s pjesmama koje u prvi plan ističu avangardističku utopijsku ,vertikalu“ na kojoj autorova poetika počiva. A to nije samo linija odabrane književne tradicije čije su uporište Majakovski (kao „svjetionik“) i Kručonih, za kojima slijedi niz drugih ruskih futurista/avangardista, a u domaćim okvirima čine je Krleža, Cesarec i (implicitno) Ujević i Kranjčević. Štoviše, to je i „,vertikala“ Oktobarske revolucije čiji historijat i parole Sever također priziva, moglo bi se reći da ih s povijesne distance citira ili ,stilizira“6 (podnaslov pjesme Plakat glasi: u stilu ondašnjih plakata), a cilj citata odnosno stilizacije evidentno je težnja prema očuvanju snage njihove izvorne poruke. Ta snaga tim je važnija jer Severov je lirski subjekt svjestan da „More Revolucije / Često ima neveru / A neveru ne možeš tek tako / Preveslati“" (Sever, 1989, 171) jer „uvijek netko prima mito / uvijek netko vara“ (Sever, 1989, 167). Drugim riječima, u Severovim pjesmama na šaljiv način ističe se da je revolucionarni projekt avangarde obilježen krizom, no unatoč tome, kako Parežanin $(2015,174)$ piše, optimalna projekcija optimistično

\footnotetext{
${ }^{6}$ Parežanin Severovu citatnost čita koristeći Bahtinov pojam stilizacije; u njenom je temelju dijalogična gesta istodobnog objektiviranja i distanciranja od tuđega gledišta te njegovoga preuzimanja i uokvirivanja: temeljne su strategije stilizacije ,uvijek vezane uz uokvirivanje tuđega glasa“ (Parežanin, 2015, 170).
} 
se potvrđuje, jer prevratničku tradiciju treba održati živom, i to unutar ideološkog okvira koji je nominalno i simbolički prisvaja. Biti lijevi avangardist u socijalističkome dijelu svijeta, piše Brebanović povodom Krleže, značilo je ostvarenje političkih snova, ali i ,jednu vrstu društvene i stvaralačke prilagođenosti koja [...] ne deluje preterano autentično, a još manje avangardno" (Brebanović, 2016, 187). Da pozicija lijevoga avangardista u socijalizmu ne mora nužno otupiti oštricu i autentičnost avangardističkoga stava na sasvim drugačiji način od Krleže zasigurno pokazuje i Severovo stvaralaštvo koje u Krleži uz Cesarca nalazi „hrid“ na koju se može osoviti revolucionarna okomica: „Ali mi imamo hrid / Našega starca / A. Cesarca. / Imamo KRLEŽU MIROSLAVA: / Njemu: mirovaja SLAVA“ (Sever, 1989, 171).

Upravo se u odnosu spram Krleže ističe razlika između Severa i Ivšića, koji zamjera Krleži „estetski konzervativizam“, dogmatizam, kao i kompromitiranje u suradnji s vlastima (Ivšić, 2002, 94-95); za njega je suradnja Krleže i Marka Ristića jedna od „najvećih nesreća koje su zadesile intelektualni život na Balkanu“ (Ivšić, 2002, 95). Nasljeđe povijesne avangarde Ivšić i Sever vrednuju na dijametralno suprotan način iako, paradoksalno, i jedan i drugi imaju povjerenje u optimalnu projekciju kao jednu od središnjih odrednica avangarde. Ovdje se vrijedi prisjetiti da Flaker u svom objašnjenju optimalne projekcije ističe mogućnost „izbornosti“ kao njezinu ključnu sastavnicu - a to je činjenica da je svaki stvaratelj oblikuje vlastitom političkom imaginacijom u skladu s vlastitim habitusom kao njezinim uporištem ${ }^{7}$. I jedan i drugi autor pritom imaju veliko povjerenje u snagu riječi i poezije, kao i njezine izvedbe - ona treba biti upućena svima: „Pjesma mora imati privlačnost, izvjesnu dozu komunikativnosti prema najobičnijem čovjeku, prema laiku koji se ne razumije u poeziju. [...] Dakle, nikako komorna poezija, jer moramo nastojati da nas što više ljudi čita“ (Sever, 1970, 1262); odnosno: „Poezija nije stvar specijalista, umjetnika: ona je život, koji treba da izdrži pred mišlju, ona je misao, koja treba da izdrži pred životom..." (Ivšić, 2002, 27)

${ }^{7}$,»OPtimalna projekcija« ne označuje idealno strukturirani prostor budućnosti, ona ga i ne nastoji definirati, već označuje kretanje kao biranje »optimalne varijante« u prevladavanju zbilje“ (Flaker, 1982, 68). Flaker je međutim pretjerano restriktivan u vremenskoj primjeni značenja ovoga pojma pa smatra da već kasne 1920-e donose nepovratan slom optimalne projekcije te da je u nadrealizmu više i nema (Flaker, 1982, 344)! 
Dok se kod Ivšića i Severa - iako na različite načine - i dalje očituje povjerenje u optimalnu projekciju avangarde, kod ,jezičnih“ pjesnika 1970-ih situacija je sasvim drugačija. Poezija Josipa Severa postala je svojevrsnim modelom mlađih generacija (a ne smije se izostaviti ni važan utjecaj slovenske neoavangarde i Tomaža Šalamuna) $)^{8}$, pa pjesništvo jezičnoga iskustva 1970-ih i 1980-ih odnosi prevagu nad nastavljačima dotada dominantne egzistencijalne struje. Poezija se kod pjesnika okupljenih oko časopisa Pitanja (Borben Vladović, Ivan Rogić Nehajev, Zvonko Maković, Milorad Stojević, Darko Kolibaš i dr.) okreće ispitivanju vlastitog medija, što je praćeno razvijenom teorijskom refleksijom. Književni kritičari, koji su najčešće i sami autori, upućuju na to da se u pjesnika razvija „znanstvena svijest o jeziku“ (Maleš, 1980, 43), koja ima uporište u poststrukturalizmu bliskom pozicijama grupe teoretičara oko pariškog časopisa Tel Quel. Pojmovi marksističko-dekonstrukcijske provenijencije poput proizvodnje, prakse, materijalnosti označitelja, pisanja, logocentrizma, traga i razlike postaju temeljem refleksije o poeziji, a kasnije i dijelom akademskog žargona. Na djelu je unutarnja kritika jezika kao transparentnog medija, pukog prenositelja poruke, ideje ili emocije; pjesma je prije svega tekst u smislu artefakta koji, riječima Petera Bürgera $(2007,96)$, ne želi prikriti „,̌injenicu svoje proizvedenosti“, a pjesnik nije ,genij“ nego proizvođač. Radi se o sličnome procesu koji Anna Katharina Schaffner prepoznaje u konkretizmu: formalni postupci povijesne avangarde nasljeduju se i razrađuju na pozadini suvremenih teorijskih spoznaja o jeziku i uvjetima njegove društvene uporabe.

Kod ovih pjesnika izostaju međutim pokušaji artikulacije utopijske perspektive ili poveznice estetskog i političkog. Reprezentativan je u tome smislu Mrkonjićev tekst „Ideologija i pisanje“, objavljen u zborniku Slovo razlike - teorija pisanja (1970), svojevrsnom „manifestu“ pitanjaške

${ }^{8}$ Može se reći da je val poratnog avangardizma u Jugoslaviji krenuo upravo iz Slovenije, pa se govori o avangardističkom desetljeću od 1965. - 1975. godine, koje obilježavaju djelatnost književno-likovne grupe OHO, omladinski časopisi Problemi i Tribuna te nastup pisaca među kojima je uz Šalamuna važno spomenuti i Francija Zagoričnika, Iztoka Geistera, Marka Pogačnika, Matjaža Hanžeka i drugih. U Srbiji su također važna avangardistička uporišta krajem 1960-ih i 1970-ih časopis Rok (1969), pjesničke grupe Kôd i ( $\exists$ te časopis na mađarskom Új symposion te imena koja se oko njih okupljaju poput Slobodana Tišme, Vujice Rešina Tucića, Otta Tolnaija, Katalin Ladik, Bore Ćosića i dr. (v.: Čegec, 1983; Šuvaković, Đurić, 2003). 
pjesničko-teorijske grupe. U njemu autor pledira za književnost kao materijalnu praksu oslobođenu službeničkog položaja spram ideologije koja jezik uvijek tretira kao izraz neke pretpostavljene stvarnosti, a svaku upotrebu riječi s onu stranu reprezentacije proglašava verbalizmom (Mrkonjić,1970, 186). Svoje uvide o ideologiji Mrkonjić eksplicitno povezuje s telquelovskom marksističkom kritikom građanske ideologije, ali ih proširuje i na kontekst ,,autoritarnog socijalizma“ (Mrkonjić, 1970,186) i u jednom i u drugom političkom sustavu na djelu je svojevrsno porobljavanje riječi. Politička subverzivnost književnosti u odnosu na dominantnu ideologiju - bila ona kapitalistička ili ,,autoritarno“ socijalistička - stječe se sada na samoj razini teksta, u oslobađanju ,energije pisanja“ od nametnutih kodova politike i književne tradicije. Vlastiti otpor poezija sada crpi isključivo braneći svoju autonomiju i posebnost.

Problem je međutim u tome što se ideologija ne može svesti na Ideologiju, odnosno na kategoriju ,transcendentalnog označenog“ kao smisla koji uvijek prijeti porobiti inherentnu slobodu jezičnog znaka. Isto se tako ni jugoslavenski samoupravni socijalizam ne može svesti na sovjetski ,autoritarni“" (ako je Mrkonjić uopće na taj i mislio), kao što se prvi bitno razlikuje i od kapitalizma Zapada. Domet tekstualnoga otpora stoga ostaje dvojben, čega je i Mrkonjić svjestan kada kasnije ističe da je poezija koja želi dokinuti smisao zapravo sukladna, a ne suprotna poeziji koja se spremno angažira za političke ciljeve (Mrkonjić, 1991, 368), a time valjda i otvoreno dodvorava vladajućoj ideologiji. Severova gesta sinteze ovih polova - estetskog radikalizma i otvorenog angažmana - pri čemu drugi ne kompromitira prvi, kao što ni prvi ne obesmišljava drugi, u kontekstu pjesnika koji se javljaju 1970-ih i 1980-ih ostaje izoliran primjer. „Mlada avangarda“" mora manevrirati u kulturnom i ideološkom prostoru koji joj nipošto ne uskraćuje mjesto, ali je ipak smješta na rub ${ }^{9}$. Ideologija je stoga

${ }^{9}$ U intervjuu za Quorum 1985. slovenski (neo)avangardist i konkretistički pjesnik Franci Zagoričnik razlučuje tretman umjetničke avangarde unutar šireg socijalističkog konteksta: staljinizam je ukida (npr. u Čehoslovačkoj 1968), dok se u samoupravnom socijalizmu država „,ne miješa u proces bitka i žitka avangardne književnosti“ (Zagoričnik, 1985, 16). Problem otpora prema avangardi u ovom se kontekstu međutim premješta na razinu kulturne politike urednika i izdavačkih kuća koji doprinose marginalizaciji i slaboj vidljivosti avangardističkih publikacija (Zagoričnik, 1985, 16). Zagoričnikovi se zaključci odnose na slovenski kontekst, ali vrijede za cijelu Jugoslaviju 1970-ih i 1980-ih. 
za ove pjesnike mrski tlačitelj bez obzira na odijelo koje nosi; traže se razlike $\mathrm{i}$ individualnost - na pragu smo postmodernizma.

No i put prema postmodernizmu određen je okretanjem prema avangardi. Za pjesnike i kritičare poput Branka Maleša ili Branka Čegeca pojam avangarda iznova je aktualan, a njihovo posezanje za njime govori o njegovoj aktualnosti kod mlađe generacije pisaca koja traži svoje mjesto u književnome polju, okupljajući se krajem 1970-ih oko kratkotrajnog časopisa Off, a od sredine 1980-ih oko časopisa Quorum (pjesnici poput Anke Žagar, Delimira Rešickog, Miroslava Mićanovića, Krešimira Bagića i dr.). Ono što se kasnije nazvalo postmodernizmom u poeziji, za njih je tada još jedna varijanta avangarde, ali u povijesnoj perspektivi, pa Čegec piše o ,presvlačenju avangarde“" $u$ istoimenoj publikaciji. Ovi su autori svjesni da je avangarda iza njih, kao tek jedna od dostupnih tradicija za kojima pjesnik poseže, ona je dio arhiva cjelokupne kulture. Kritičari to nazivaju „sintetičkim pjesništvom“ (Čegec, 1983, 15), ,aleksandrijskom situacijom“ ili „novim tradicionalizmom“ (Maleš, 1980, 32), ili jednostavno postavangardom - postmodernizam se na koncu prihvaća kao najpogodniji pojam za ove geste osvrtanja unazad. Avangarda je tako jedna od raspoloživih tradicija, no povlaštena je zbog svoje „tragalačke naravi“ (Čegec, 1983, 15), ona je ,glasonoša ponovljena rođenja i nove dinamizacije umjetničke prakse“ (Čegec, 1983, 33). Oslonac na avangardu u postavangardnoj fazi vidljiv je ponajprije na razini strukturiranja pjesničkog teksta, što Maleš u osvrtu na pjesništvo Milorada Stojevića opisuje sintagmom „semantički konkretizam“, koja se odnosi na formu teksta u kojem je potenciranje označiteljske razine združeno s novim vrednovanjem konotativnih značenja riječi (Maleš, 1980, 30-32). U pjesničkom kontekstu, dakle, postmodernizam nipošto nije smrt avangarde, već kreativna asimilacija nekih njezinih aspekata; da su avangarda i neoavangarda za postmodernizam 1980-ih aktualne, potvrđuje i činjenica da je časopis Quorum u dva svoja broja kao posebne priloge u rubrici „reaktualizirani tekstovi“ donio pretisak Severova Diktatora i Đerdana Josipa Stošića. Quorum je ujedno i časopis koji je u drugoj polovici 1980-ih avangardama davao istaknuto mjesto u svojim prilozima i tematima; riječ je o časopisu koji nije bio samo hrvatski, već i jugoslavenski fenomen, važno čvorište tadašnje mlade jugoslavenske kulture s uporištem u književnosti, rock-glazbi, vizualnim medijima i postmodernoj teoriji. 
Devedesetih godina rasprave o avangardi u Hrvatskoj jenjavaju, povijesna avangarda postala je dio književnoga kanona i sastavnim dijelom nacionalne književnopovijesne naracije, a u raspravama o postmodernizmu utopijske projekcije postale su talac propalih totalitarnih sustava. Iako je „smrt avangarde“, kako je ustvrdio van den Berg (2005a) u članku o toj temi, postala popularna parola početkom novoga milenija, potreba deklariranja njezine smrti paradoksalno svjedoči o tome da povijesna avangarda i u svom posthumnom periodu sadrži neku životnu jezgru. Dapače, kako tvrdi Brebanović $(2016,35)$, ona je od jednoga trenutka postala ,stalno moguća", kao tradicija hereze i radikalnih zahtjeva o promišljanju odnosa umjetnosti i života, estetike i politike. Ako se ideja kontinuiteta avangarde prihvati kao temelj pristupa tome području, odnosno ako se uvaži činjenica da se povijesna avangarda ne može razumjeti bez svojih kasnijih umjetničkih i kritičkih reinterpretacija, tada proučavati avangardu u Hrvatskoj danas nužno znači i na novi način valorizirati njezino mjesto i značenje u okvirima socijalističkoga društva i jugoslavenske kulture. Drugim riječima, proučavanje avangarde treba pokazati da njezina historizacija nikada ne može biti završena te da su pitanja koja nam ona omogućuje postaviti jednako relevantna za sadašnjost kao i za prošlost.

\section{Literatura}

Bagić, K. (1994). Živi jezici - poetska pisma Ivana Slamniga, Josipa Severa i Anke Žagar. Zagreb: Naklada MD.

van den Berg, H. (2005a) On the Historiographic Distinction between Historical and Neo-Avant-Garde. U: Avant-Garde / Neo-Avant-Garde. Ur. D. Scheunemann, Amsterdam-New York: Rodopi, str. 63-74. https://doi.org/10.1163/9789401202589_005. van den Berg, H. (2005b) The Life and Death of the Avant-garde on the Battlefield of Rhetoric - and Beyond. „Forum, Postgraduate Journal of Culture and the Arts“ br. 1, str. 1-10. http://www.forumjournal.org/article/view/538/824. 10.11.2019. van den Berg, H., Fähnders, W. (2013). Leksikon avangarde. Prev. S. Krajčević. Beograd: Službeni glasnik.

Brebanović, P. (2016). Avangarda Krležiana - pismo ne o avangardi. Zagreb: Naklada Jesenski i Turk \& Arkzin.

Bürger, P. (2007). Teorija avangarde. Prev. N. Medved. Zagreb: Izdanja Antibarbarus. Čegec, B. (1983). Presvlačenje avangarde - 7 tekstova o književnosti avangarde i postavangardnih gibanja. Zagreb: Pitanja. 
Flaker, A. (1976). Stilske formacije. Zagreb: Liber.

Flaker, A. (1982). Poetika osporavanja. Zagreb: Školska knjiga.

Ivšić, R. (2002). U nepovrat, opet. Zagreb: Nakladni zavod Matice hrvatske.

Maleš, B. (1980). U obzoru novog hrvatskog pjesništva (pjesnička proizvodnja pisaca rođenih poslije rata, 1946-1958). „Off“ br. 2, str. 27-42.

Maleš, B. (1985). Retro-pogled u skladište historijsko-avangardističke prakse. „Quorum“ br. 3, str. 23-34.

Mrkonjić, Z. (1970). Ideologija i pisanje. U: Slovo razlike - teorija pisanja. Zagreb: Edicija Pitanja, str. 183-201.

Mrkonjić, Z. (1971). Suvremeno hrvatsko pjesništvo (razdioba). Zagreb: Biblioteka Kolo.

Mrkonjić, Z. (1991). Grupni portret s pukotinom. U: Izvanredno stanje - književni ogledi. Zagreb: Grafički zavod Hrvatske, str. 359-370.

Oblučar, B. (2015). Narcis Radovana Ivšića - poema u obzoru avangarde. U: Komparativna povijest hrvatske književnosti. Zbornik radova XVII. Poema u hrvatskoj književnosti: problem kontinuiteta. Ur. C. Pavlović, V. Glunčić Bužančić, A. Meyer Fraatz. Split: Odsjek za komparativnu književnost-Zagreb: Filozofskoga fakulteta Sveučilišta u Zagrebu.

Oraić Tolić, D. (1989). Civilizacijski nomadizam Josipa Severa. U: J. Sever. Borealni konj. Zagreb: Mladost, str. 5-20.

Parežanin, L. (2015). Pjesništvo Josipa Severa i problemi proučavanja avangarde. „Umjetnost riječi“ br. 1-2, str. 155-176.

Schaffner, A. K. (2006). Inheriting the Avant-Garde: On the Reconciliation of Tradition and Invention in Concrete Poetry. U: Neo-Avant-Garde, ur. D. Hopkins. Amsterdam-New York: Rodopi, str. 97-117. https://doi.org/10.1163/9789401203760_007.

Sever, J. (1970) Uvodna riječ Josipa Severa. „Pitanja“ br. 13-14, str. 1261-1262.

Sever, J. (1989). Borealni konj. Zagreb: Mladost.

Šuvaković, M., Đurić, D. (ur.) (2003). Impossible Histories - Historical Avant-gardes, Neo-avant-gardes, and Post-avant-gardes in Yugoslavia, 1918-1991. CambridgeLondon: MIT Press.

Zagoričnik, F. (1985). Avangarda sada-interview. „Quorum“ br. 0, str. 15-23. 